\title{
Sales Force Automation Acceptance: An Exploratory Study Of The Role Of Job Experience
}

Jian Guan, (Email: jeff.guan@louisville.edu), University of Louisville Robert M. Barker, University of Louisville David J. Faulds, University of Louisville Stephan F. Gohmann, University of Louisville

\begin{abstract}
User perceptions of new technologies may ultimately affect their acceptance of that technology. Recent research has identified a clear connection between user perceptions of Sales Force Automation and their acceptance of Sales Force Automation technologies. Anecdotal evidence suggests that relative to less experienced salespeople, more experienced salespeople tend to have more negative perceptions of sales force automation. This paper examines the relationship between job experience and perceptions of a sales force automation system. The results are based on a survey of 1,657 salespeople about their perceptions of several aspects of a sales force automation system in a large sales organization. This study finds significant differences by sales experience in areas such as perceived productivity/efficiency gain, perception of sales force automation as a micromanagement tool, and user satisfaction with system functionality. Based on these results several important managerial implications for the adoption of a sales force automation system are suggested.
\end{abstract}

\section{Introduction}

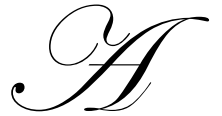

utomation of tasks through the use of information technology is an effective method to improve organizational efficiency. Although marketing was among one of the first functional areas to adopt information technology (McLeod et al., 1982; Li et al., 2001), the utilization of sales force automation (SFA) technologies is a more recent phenomenon. SFA, as a technical innovation, has become very popular in the last decade (Blodgett, 1995; Schafer, 1997; Stein, 1998). SFA has been defined as the use of information technology by the sales force in selling and administrative activities (Morgan and Inks, 2001). Defined as such, SFA offers many potential benefits such as increases in sales effectiveness and efficiency, improved productivity, and enhanced customer relationship management (Morgan and Inks, 2001; Gondert, 1993; Johnston, 1995; Speier and Venkatesh, 2002; Fisher, 1998). While the potential benefits of successful SFA adoption can be numerous, implementation of these systems is often complex and difficult. Industry studies have reported SFA failure rates from 55 to 60 percent (Schafer, 1997; Stein, 1998).

The potential rewards and the relatively high risk of failure in SFA implementations have attracted the attention of researchers in recent years (Keillor et al., 1997; Parthasarathy and Sohi, 1997; Engle and Barnes, 2000; Morgan and Inks, 2001; Effmeyer et al., 2001; Pullig et al., 2002; Speier and Venkatesh, 2002). An emerging focus in the literature is the acceptance of SFA technologies by the sales force. User acceptance, which is critical to the success of the SFA system, has been found to be influenced by user perceptions of the SFA system (Keillor et al., 1997; Morgan and Inks, 2001; Speier and Venkatesh, 2002).

This paper further examines the effect of user perceptions on acceptance of SFA technology by studying the effect of salespeople's job experience on their perceptions of the SFA technology. The paper describes a study that examines association between sales experience and perceptions about an SFA system implemented across the 
United States Army Recruiting Command. A survey was administered to 1,657 recruiting personnel (salespeople) regarding their perceptions of the SFA system after its implementation. The results indicate that recruiters with less experience are more likely to have favorable perceptions about the SFA system relative to their more experienced counterparts. In particular, the results indicate a significant difference by experience in areas such as perceived productivity gain, perception of SFA as a micromanagement tool, and user satisfaction with system functionality.

The next section develops hypotheses concerning the association between sales experience and perceptions of SFA functionality, SFA training, productivity, and micromanagement. The methodology section describes the research design, the administration of the survey, and the statistical methods used to analyze the data. The results section provides a detailed description and discussion of the survey results and hypothesis testing. The paper ends with a discussion of implications and conclusions.

\section{Research Conceptualization}

Individual differences can lead to different attitudes and perceptions about a technology, which in turn affect subsequent use of the technology (Regan and Fazio, 1977; Ajzen, 1991; Speier and Venkatesh, 2002). In particular, age and job experience can influence the acceptance of technology. Older workers generally tend to have more negative perceptions about a given technology (Morris and Venkatesh, 2000). For salespeople, younger individuals are likely to have more positive perceptions of technology (Speier and Venkatesh, 2002) and are more likely to welcome its use (Parthasarathy and Sohi, 1997).

Only one study examines the relationship between the job experience of salespeople and their perceptions of technology (Keillor et al., 1997). However, their study investigates the relationship between attitudes toward technology in general, job experience, and productivity prior to SFA implementation. They find that less experienced salespeople are less resistant to the use of technology in general.

SFA has been introduced partly in response to increasing pressure to reduce costs and increase profits (Johnston, 1995). Erffmeyer and Johnson (2001) find that sales managers and salespeople identified improving efficiency as the major goal of SFA. It has also been shown that SFA can lead to higher productivity (Engle and Barnes, 2000; Pullig et al., 2002). Improved productivity/efficiency is important to salespeople, as it has a direct impact on their ability to generate commissions. As a consequence, a perception of a productivity/efficiency gain through the use of SFA technologies should be more likely to lead to better acceptance of the SFA system. Given the known effect of experience and age on perceptions of technology (Keillor et al., 1997; Morris and Venkatesh, 2000; Speier and Venkatesh, 2002; and Parthasarathy and Sohi, 1997), it is likely that more experienced (older) salespeople will have a less positive perception of productivity/efficiency gain through SFA than less experienced salespeople. More experienced salespeople are more entrenched in the current sales processes and therefore less likely to be willing to modify their behavior for an uncertain return.

Hypothesis 1: More experienced salespeople are less likely to perceive productivity/efficiency gains than less experienced salespeople.

Salespeople resist SFA technologies because they view the introduction of SFA as a tool for management to micromanage them (Gondert, 1993; Stein, 1998; Falvey, 1994; Rivers and Dart, 1999). SFA technologies allow better tracking and monitoring of a part of the organization that has traditionally operated somewhat independently (Rivers and Dart, 1999). As a result, when faced with the prospect of constantly being supervised electronically by the home office and management, salespeople naturally increase their resistance to SFA (Gondert, 1993). Prior to the implementation of the system, all salespeople had relative autonomy in the sales process. Autonomy, as a job core characteristic, has been reported by Hackman and Oldham (1980) to be an important motivational element in any job. The er

osion of that autonomy for the experienced salespeople, due to the implemented SFA system, would be greater since they have experienced this autonomy longer. 
Hypothesis 2: More experienced salespeople are more likely to perceive SFA as a micromanagement tool than less experienced salespeople.

User satisfaction with system functionality has been shown to be a good indicator of information technology success (Mahmood et al., 2000). Areas of satisfaction with system functionality include perceptions of information accuracy, system flexibility, time requirements, and overall system effectiveness. The level of sales experience will likely moderate perceptions in each of these areas. For example, more experienced salespeople are more likely to discriminate about the accuracy of the information since they are more likely to have proven sales techniques that fit their individual sales styles. The SFA system replaces those techniques with its own. As a result salespeople lose discretion over the use of their time, the information sources they use, and how to best tailor their efforts to their personal style.

Hypothesis 3: More experienced salespeople are less likely to be satisfied with SFA system functionality than less experienced salespeople.

\section{Research Setting and Methodology}

The research described in this investigation was requested by senior officers in the United States Army Recruiting Command (USAREC). A general perception existed among USAREC's research staff that the Army's newly implemented SFA system was not sufficiently integrated into the Army's complex administrative structure or the day-to-day recruiting/sales process.

The administrative structure for USAREC is presented in Figure 1. The command is divided into five brigades, 41 battalions, 270 companies, and more than 1,600 recruiting stations (RSID). The RSID territories are distinct geographical entities that are equivalent to sales territories in the private sector and represent the foundation of USAREC's organizational structure.

The organizational structure represented in Figure 1 has traditionally been employed to establish and monitor recruiting/sales goals. Historically, the second brigade located in the southeast section of the USA has produced the highest contract production; the third brigade, located in the Great Lakes area, has registered the lowest contract production.

To assist the recruiting force in processing the 20 million contacts received per year, the Army Recruiting Information Support System (ARISS) was designed in the late 1990s and fully deployed across the recruiting command in the year 2000. This SFA system provides a single source of automation that the Army uses to support critical sales tasks ${ }^{1}$ at the recruiting station level and sales management tasks at the company, battalion, and brigade levels. Therefore, ARISS integrates state-of-the-art computer technology with various recruiting tasks and thus serves as the Army's SFA.

The adoption of ARISS by USAREC provided an ideal setting to examine the relationship between job experience [of sales people] and perceptions of a newly adopted SFA system. All Army recruiting personnel receive the same sales training program, from the same Army instructors, at the same Army installation. In addition, all recruiters at the same level are compensated at the same rate and all recruiting stations (sales offices) are required to follow identical sales procedures and processes. Marketing strategy variables, such as national and local advertising, public relations and publicity programs are also uniform across the nation. The unique organizational environment of USAREC provided an ideal setting to investigate the relationship between the sales experience of recruiters and their perceptions of a newly implemented SFA system.

To investigate the relationship between experience and user perceptions of the SFA system, a thorough review of academic, military, and industry studies on SFA systems was conducted. Following the review of all relevant literature, a series of depth interviews were undertaken with personnel representing all levels of USAREC's

\footnotetext{
${ }^{1}$ The sales tasks include receiving, managing and accessing information about potential Army recruits.
} 
management (recruiting station, company, battalion, and brigade) to identify and isolate issues and concerns about the SFA system. Based on the information gleaned during the depth interviews and the literature review a survey instrument was developed and extensively pre-tested on subjects representing all levels of management. The instru-

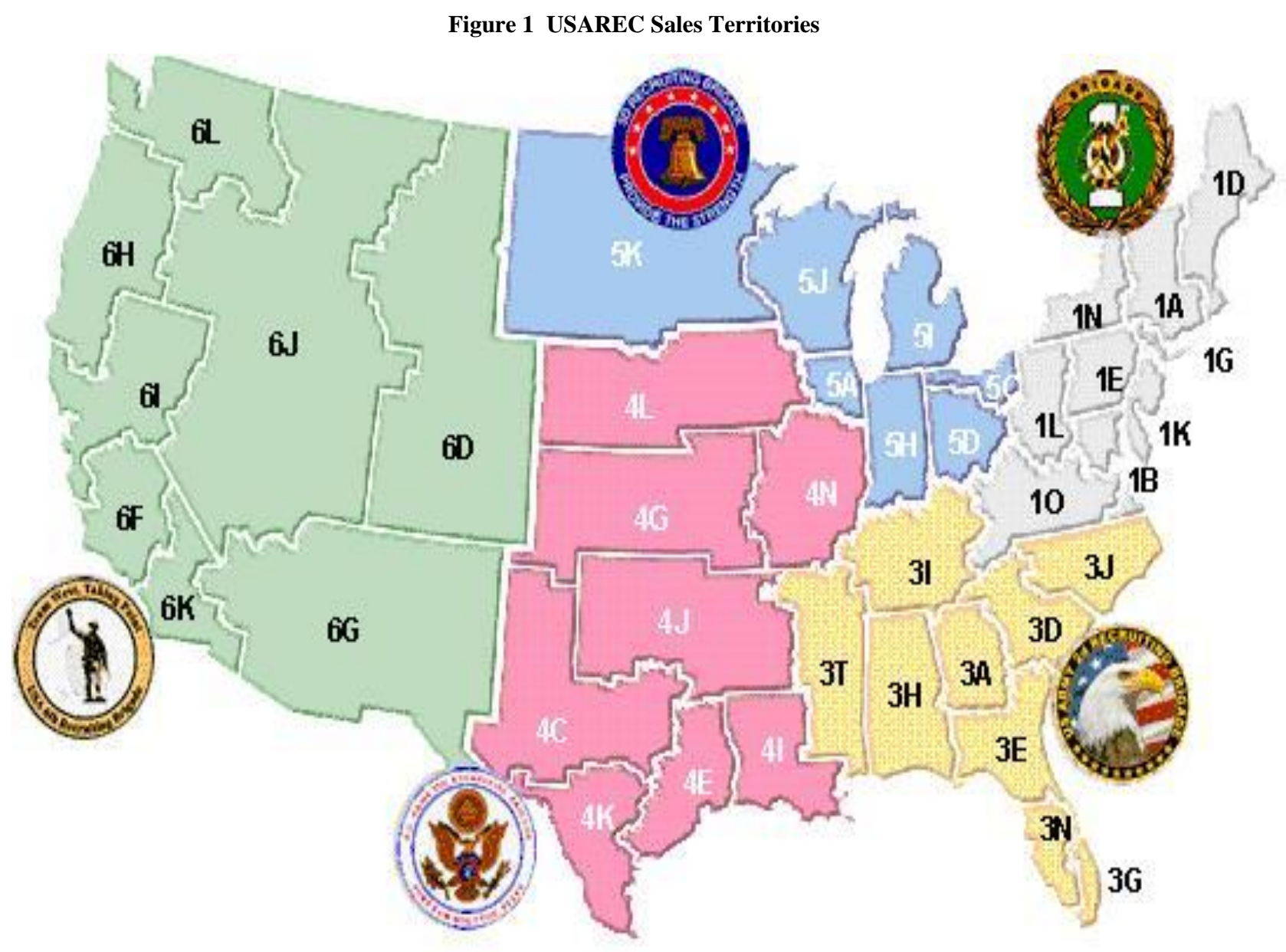

ment was revised accordingly and administered to a national sample of USAREC personnel during the fourth quarter of 2001. Approximately 3,350 recruiting personnel received the survey and 1,647 returned the completed questionnaire resulting in a response rate of 47 percent.

To assess non-response error, a trend analysis was conducted that involved dividing the respondents into three groups: early respondents, intermediate respondents, and late respondents. A chi square contingency table analysis was performed across the three groups comparing their responses to each statement contained in the survey instrument. The results of this analysis indicated that the three groups were homogeneous with respect to their responses to the statements. 
In the analysis of the survey results, the salespeople are divided into two groups based on their years of experience in recruiting. The Army has traditionally employed a rotation system, assigning soldiers to the recruiting force for a two-year period. However, personnel that have requested and qualified for a Military Occupational Status (MOS) of R-76 continue beyond the normal two-year period and function as career recruiters. Based on the longevity of the sales force, the Army requested that two years be the categorization for experience. Those recruiters with two years of experience or less are classified as "the less experienced group" and those with greater than two years of experience are classified as "the more experienced group." Among the 1,657 salespeople that returned the survey, $1,111(67 \%)$ are in the less experienced group and $546(33 \%)$ are in the more experienced group. Over two thirds of the recruiters fall in the age range of 28 to 35, a relatively tight distribution.

The respondents were asked to respond to statements about the SFA system with a seven point scale beginning with "strongly disagree," "disagree," "slightly disagree," "neutral," "slightly agree," "agree," to "strongly agree." Two methods are used to analyze how these statements differ by level of experience. The first method applies a chi-square test to examine the association between sales experience and the responses to each statement. The contingency tables indicate that for many of the statements there are strong negative perceptions.

Since the contingency table accounts only for variation in responses to the statement by experience, a regression analysis is used to hold constant other factors that may influence user perceptions of the system. These factors are the number of hours worked per week by the recruiter, the number of months that the recruiter's station met mission (achieved sales goals), and the recruiter's perception about the adequacy of the training he/she received.

Recruiters were asked to indicate the number of hours they worked in an average week with possible responses ranging from: less than 40 hours, 40 to 50 hours, 51 to 60 hours, 61 to 70 hours, and greater than 70 hours. Recruiter attitudes about the SFA system may differ by number of hours worked per week. Recruiters who work more hours may see the system as a further hindrance to their routine and may express a more negative attitude toward the system.

Productivity is measured by the number of months a recruiting station met its sales goals, or mission, in the past year. If a recruiting station failed to achieve its sales objectives it is logical to assume that the failure to do so may be attributed to the SFA system. As such, recruiters assigned to stations that consistently failed to meet sales goals may be more likely to have negative impressions about the SFA system.

Recruiters were also asked to rate, on a seven point scale, their perception of the adequacy of the training they received. Training has been recognized as critical to the successful acceptance of SFA (Rasmussen, 1999; Erffmeyer and Johnson, 2001). Morgan and Inks (2001) find that salespeople are more likely to accept SFA if they perceive their training is adequate. As such, recruiters who found their training to be adequate should be more likely to find the system acceptable.

\section{Results}

To understand the overall responses, Tables 1 through 3 show how the responses differ by experience. These contingency tables show a strong association of experience with most of the responses. There tends to be a negative association between experience and perception of productivity/efficiency gain, perception of SFA as a micromanagement tool, and satisfaction with system functionality.

Table 1 shows that user perceptions of productivity gain associated with the SFA are negatively affected by sales experience. The respondents were asked about their perceptions of productivity gains at both the individual level and the sales office level. The less experienced salespeople were more likely to agree with all four of the productivity/efficiency statements, indicating that they perceived more productivity gain resulting from the utilization of the SFA than the more experienced salespeople. The percentage of more experienced respondents who disagreed with each productivity statement was at least 15 percentage points higher than the percentage for the less experienced salespeople. The overall responses indicate a general dissatisfaction with the productivity of the system. 
Over 40 percent of the responses for each statement were negative. The lack of agreement with these statements is an indication that the system is not perceived to improve the productivity of the sales force.

Table 1: Perceptions of Productivity/Efficiency Gain by Experience

\begin{tabular}{|c|c|c|c|c|c|c|c|c|c|}
\hline Statement & $\begin{array}{l}\text { Experience } \\
\text { Level }\end{array}$ & $\begin{array}{c}\text { Strongly } \\
\text { Disagree } \\
(\%) \\
\end{array}$ & $\begin{array}{c}\text { Disagree } \\
(\%)\end{array}$ & $\begin{array}{c}\text { Slightly } \\
\text { Disagree } \\
(\%) \\
\end{array}$ & $\begin{array}{c}\text { Neutral } \\
(\%)\end{array}$ & $\begin{array}{c}\text { Slightly } \\
\text { Agree } \\
(\%) \\
\end{array}$ & $\begin{array}{c}\text { Agree } \\
(\%)\end{array}$ & $\begin{array}{c}\text { Strongly } \\
\text { Agree } \\
(\%) \\
\end{array}$ & $x^{2}$ \\
\hline \multirow{3}{*}{$\begin{array}{l}\text { The system helps } \\
\text { me achieve my } \\
\text { office sales goal }\end{array}$} & $\mathrm{LE}^{*}$ & $\begin{array}{c}157 \\
(14.1 \%)\end{array}$ & $\begin{array}{c}221 \\
(20.0 \%)\end{array}$ & $\begin{array}{c}138 \\
(12.4 \%)\end{array}$ & $\begin{array}{c}373 \\
(33.6 \%)\end{array}$ & $\begin{array}{c}146 \\
(15.1 \%)\end{array}$ & $\begin{array}{c}70 \\
(6.3 \%)\end{array}$ & $\begin{array}{c}6 \\
(0.5 \%)\end{array}$ & \multirow{2}{*}{$37.3^{\mathrm{a}}$} \\
\hline & ME & $\begin{array}{c}121 \\
(22.2 \%)\end{array}$ & $\begin{array}{c}139 \\
(25.5 \%)\end{array}$ & $\begin{array}{c}75 \\
(13.7 \%)\end{array}$ & $\begin{array}{c}128 \\
(23.4 \%)\end{array}$ & $\begin{array}{c}51 \\
(9.3 \%)\end{array}$ & $\begin{array}{c}30 \\
(5.5 \%)\end{array}$ & $\begin{array}{c}2 \\
(0.4 \%)\end{array}$ & \\
\hline & Overall & $16.8 \%$ & $21.7 \%$ & $12.9 \%$ & $30.2 \%$ & $11.9 \%$ & $6.0 \%$ & $0.5 \%$ & \\
\hline \multirow{3}{*}{$\begin{array}{l}\text { The system has } \\
\text { made me more } \\
\text { productive as a } \\
\text { sales person }\end{array}$} & LE & $\begin{array}{c}104 \\
(9.4 \%)\end{array}$ & $\begin{array}{c}188 \\
(16.9 \%)\end{array}$ & $\begin{array}{c}129 \\
(11.6 \%)\end{array}$ & $\begin{array}{c}423 \\
(38.1 \%)\end{array}$ & $\begin{array}{c}176 \\
(15.8 \%)\end{array}$ & $\begin{array}{c}80 \\
(7.2 \%)\end{array}$ & $\begin{array}{c}11 \\
(1.0 \%)\end{array}$ & \multirow{2}{*}{$\underset{\mathbf{a}}{72.4}$} \\
\hline & ME & $\begin{array}{c}95 \\
(17.4 \%) \\
\end{array}$ & $\begin{array}{c}151 \\
27.7(\%) \\
\end{array}$ & $\begin{array}{c}70 \\
(12.8 \%) \\
\end{array}$ & $\begin{array}{c}121 \\
(22.2 \%) \\
\end{array}$ & $\begin{array}{c}71 \\
(13.0 \%) \\
\end{array}$ & $\begin{array}{c}37 \\
(6.8 \%) \\
\end{array}$ & $\begin{array}{c}1 \\
(0.2 \%) \\
\end{array}$ & \\
\hline & Overall & $12.0 \%$ & $20.5 \%$ & $12.0 \%$ & $32.8 \%$ & $14.9 \%$ & $7.1 \%$ & $0.7 \%$ & \\
\hline \multirow{3}{*}{$\begin{array}{l}\text { The system } \\
\text { improves my } \\
\text { productivity }\end{array}$} & LE & $\begin{array}{c}118 \\
(10.6 \%) \\
\end{array}$ & $\begin{array}{c}192 \\
(17.3 \%) \\
\end{array}$ & $\begin{array}{c}167 \\
(15.0 \%) \\
\end{array}$ & $\begin{array}{c}385 \\
(34.7 \%) \\
\end{array}$ & $\begin{array}{c}163 \\
(14.7 \%) \\
\end{array}$ & $\begin{array}{c}74 \\
(6.7 \%) \\
\end{array}$ & $\begin{array}{c}12 \\
(1.1 \%) \\
\end{array}$ & \multirow{2}{*}{$\underset{\mathbf{a}}{63.0}$} \\
\hline & ME & $\begin{array}{c}89 \\
(16.3 \%) \\
\end{array}$ & $\begin{array}{c}156 \\
(28.6 \%) \\
\end{array}$ & $\begin{array}{c}90 \\
(16.5 \%) \\
\end{array}$ & $\begin{array}{c}113 \\
(20.7 \%) \\
\end{array}$ & $\begin{array}{c}61 \\
(11.2 \%) \\
\end{array}$ & $\begin{array}{c}36 \\
(6.6 \%) \\
\end{array}$ & $\begin{array}{c}1 \\
(0.2 \%)\end{array}$ & \\
\hline & Overall & $12.5 \%$ & $21.0 \%$ & $15.5 \%$ & $30.1 \%$ & $13.5 \%$ & $6.6 \%$ & $0.8 \%$ & \\
\hline \multirow{3}{*}{$\begin{array}{l}\text { Overall the use of } \\
\text { the system has } \\
\text { improved the } \\
\text { productivity of } \\
\text { this sales office }\end{array}$} & LE & $\begin{array}{c}124 \\
(11.2 \%)\end{array}$ & $\begin{array}{c}152 \\
(13.7 \%)\end{array}$ & $\begin{array}{c}134 \\
(12.1 \%)\end{array}$ & $\begin{array}{c}415 \\
(37.4 \%)\end{array}$ & $\begin{array}{c}181 \\
(16.3 \%)\end{array}$ & $\begin{array}{c}91 \\
(8.5 \%)\end{array}$ & $\begin{array}{c}11 \\
(1.0 \%)\end{array}$ & \multirow{2}{*}{$\underset{\mathrm{a}}{62.4}$} \\
\hline & ME & $\begin{array}{c}87 \\
(15.9 \%)\end{array}$ & $\begin{array}{c}135 \\
(24.7 \%)\end{array}$ & $\begin{array}{c}86 \\
(15.8 \%)\end{array}$ & $\begin{array}{c}133 \\
(24.4 \%)\end{array}$ & $\begin{array}{c}65 \\
(11.9 \%)\end{array}$ & $\begin{array}{c}38 \\
(7.0 \%)\end{array}$ & $\begin{array}{c}2 \\
(0.4 \%)\end{array}$ & \\
\hline & Overall & $12.7 \%$ & $7.3 \%$ & $13.3 \%$ & $33.1 \%$ & $14.9 \%$ & $8.0 \%$ & $0.8 \%$ & \\
\hline
\end{tabular}

${ }^{*} \mathrm{LE}$ is less experienced, ME is more experienced

${ }^{\mathrm{a}}$ Significant at $\mathrm{p}<0.01$

${ }^{\text {b Significant at } \mathrm{p}<0.05}$

'Significant at $\mathrm{p}<0.10$

The results in Table 2 indicate that no significant differences exist between the less experienced salespeople and the more experienced salespeople in their perceptions of SFA as a tool to allow management to more closely manage the sales force. However, the more experienced salespeople are less likely than the less experienced salespeople to perceive that upper level management can use the SFA system to improve productivity. The more experienced salespeople were 13 percentage points more likely to disagree with the statement "that by closely managing the salespeople the upper management could improve the productivity of the individual sales offices." One interpretation of this result is that the more experienced salespeople are used to having more autonomy in the sales process, with less direct supervision from management. The SFA system now provides a direct link to that selling process; this offers more possibility for management to intrude upon their established sales routine. Such an intrusion will likely spur resistance from the experienced salespeople, as it lessens their freedom and flexibility to pursue and close sales without interference. The overall responses in Table 2 indicate that the respondents feel that the system is being used as a micromanagement tool. About three-fourths of the respondents agree that the purpose of the system is to allow upper level management to more closely supervise the sales force. However, only about 30 percent of the respondents indicate that upper level management could use this system to improve individual 
productivity. This supports the contention that the respondents think that the system is used to monitor their work habits rather than to improve their productivity.

Table 2: Perceptions of Micromanagement by Experience

\begin{tabular}{|c|c|c|c|c|c|c|c|c|c|}
\hline Statement & $\begin{array}{l}\text { Exp. } \\
\text { Level }\end{array}$ & $\begin{array}{c}\text { Strongly } \\
\text { Disagree } \\
(\%)\end{array}$ & $\begin{array}{c}\text { Disagree } \\
(\%)\end{array}$ & $\begin{array}{c}\text { Slightly } \\
\text { Disagree } \\
(\%)\end{array}$ & $\begin{array}{c}\text { Neutral } \\
(\%)\end{array}$ & $\begin{array}{c}\text { Slightly } \\
\text { Agree } \\
(\%)\end{array}$ & $\begin{array}{c}\text { Agree } \\
(\%)\end{array}$ & $\begin{array}{c}\text { Strongly } \\
\text { Agree } \\
(\%)\end{array}$ & $x^{2}$ \\
\hline \multirow{3}{*}{$\begin{array}{l}\text { Purpose of the } \\
\text { system is to } \\
\text { allow upper } \\
\text { management to } \\
\text { more closely } \\
\text { manage sales } \\
\text { personnel }\end{array}$} & $\mathrm{LE}^{*}$ & $\begin{array}{c}20 \\
(1.8 \%)\end{array}$ & $\begin{array}{c}26 \\
(2.3 \%)\end{array}$ & $\begin{array}{c}28 \\
(2.5 \%)\end{array}$ & $\begin{array}{c}236 \\
(20.2 \%)\end{array}$ & $\begin{array}{c}126 \\
(11.3 \%)\end{array}$ & $\begin{array}{c}399 \\
(35.9 \%)\end{array}$ & $\begin{array}{c}276 \\
(24.8 \%)\end{array}$ & \multirow[t]{2}{*}{9.5} \\
\hline & $\mathrm{ME}$ & $\begin{array}{c}7 \\
(1.3 \%)\end{array}$ & $\begin{array}{c}12 \\
(2.2 \%)\end{array}$ & $\begin{array}{c}13 \\
(2.4 \%)\end{array}$ & $\begin{array}{c}84 \\
(15.4 \%)\end{array}$ & $\begin{array}{c}71 \\
(13.0 \%)\end{array}$ & $\begin{array}{c}212 \\
(38.8 \%)\end{array}$ & $\begin{array}{c}147 \\
(26.9 \%)\end{array}$ & \\
\hline & Overall & $1.6 \%$ & $2.3 \%$ & $2.5 \%$ & $19.3 \%$ & $11.9 \%$ & $36.9 \%$ & $25.5 \%$ & \\
\hline \multirow{3}{*}{$\begin{array}{l}\text { By using the } \\
\text { system to more } \\
\text { closely manage } \\
\text { sales personnel, } \\
\text { upper } \\
\text { management can } \\
\text { improve the } \\
\text { productivity of } \\
\text { individual sales } \\
\text { offices }\end{array}$} & LE & $\begin{array}{c}116 \\
(10.4 \%)\end{array}$ & $\begin{array}{c}153 \\
(13.8 \%)\end{array}$ & $\begin{array}{c}127 \\
(11.4 \%)\end{array}$ & $\begin{array}{c}359 \\
(32.3 \%)\end{array}$ & $\begin{array}{c}177 \\
(15.9 \%)\end{array}$ & $\begin{array}{c}151 \\
(13.4 \%)\end{array}$ & $\begin{array}{c}28 \\
(2.5 \%)\end{array}$ & \multirow[t]{2}{*}{$32.5 \mathrm{a}$} \\
\hline & ME & $\begin{array}{c}82 \\
(15.0 \%)\end{array}$ & $\begin{array}{c}111 \\
(21.4 \%)\end{array}$ & $\begin{array}{c}67 \\
(12.3 \%)\end{array}$ & $\begin{array}{c}128 \\
(23.4 \%)\end{array}$ & $\begin{array}{c}81 \\
(14.8 \%)\end{array}$ & $\begin{array}{c}62 \\
(11.4 \%)\end{array}$ & $\begin{array}{c}9 \\
(1.7 \%)\end{array}$ & \\
\hline & Overall & $12.0 \%$ & $16.3 \%$ & $11.7 \%$ & $29.4 \%$ & $15.6 \%$ & $12.9 \%$ & $2.2 \%$ & \\
\hline
\end{tabular}

*LE is less experienced, ME is more experienced

${ }^{\text {a Significant at } \mathrm{p}<0.01}$

${ }^{\mathbf{b}}$ Significant at $\mathrm{p}<0.05$

${ }^{\mathrm{c}}$ Significant at $\mathrm{p}<0.10$

The responses in Table 3 further highlight the differences arising from sales experience. For multiple areas of satisfaction with system functionality, such as information accuracy, the reasonableness of time to use the systems, the flexibility of the system and effectiveness of the system, the more experienced salespeople are much more dissatisfied with the system than the less experienced salespeople. For every statement in Table 3, a larger percentage of experienced salespeople disagreed with each statement than did the less experienced salespeople. The largest difference is found for the statement, "The system helps me more effectively perform my duties," (17 percent) and the smallest difference is found for the statement, "Information provided by the system is accurate" ( 5 percent). It appears that where the statements touch on areas that address the imposition of the SFA system in the sales process, the reactions are much more strongly negative for the more experienced salespeople. The less experienced salespeople do not seem to be as concerned, as their routines are not yet fully formed, and they may be more likely to accept variances in their processes. Overall, Table 3 shows that between 36 to 50 percent of the respondents disagree with statements addressing system functionality. Many of these functionality statements can be related to productivity. If the system functions poorly, we would expect dissatisfaction with the productivity of the system.

The examination of the overall results clearly indicates a rather poor perception of the system in general. These negative perceptions are indicative of the lack of acceptance of the SFA system in this organization. What is less clear is whether the negative responses are due to reactions to perceived inadequacies in the functionality of the system, or are simply the salespeople's reaction to the system's imposition in the their selling process. More experienced salespeople have a "tried and true" selling process that works for them; therefore, they are less likely to accept a technology that substantially alters that selling process. Conversely, less experienced salespeople have not had the time to build up such a habitual selling process; they are therefore more likely to accept a new technology because it will not be perceived to be a substantial change in a process which has not been completely established. Furthermore, they can more easily integrate the system into their sales techniques. Clearly, a closer examination of 
how experience influences these perceptions can provide information about how to improve acceptance of the SFA system.

The system was fully implemented several months before the survey was conducted. As such, some of the less experienced recruiters may have not had experience with the previous system. This may lead to some bias in the results since these recruiters have nothing to compare to. Although information was not collected directly related to experience with the older system, one statement in the survey was: "The new system is a more effective method for managing sales leads than previously used methods." Any of the less experienced recruiters who had no previous system to compare to should have responded neutral to this statement. In fact, for the less experienced recruiters, 535 of the responses were neutral for this statement, while on average only 322 of the responses were neutral for the other statements used in this study. To alleviate the potential bias in responses from those who had no experience with the previous system, these 535 respondents were omitted and all of the analyses in this paper were reexamined without their responses. In all cases, the statistical significance and results were quite similar to those reported.

The results from the contingency tables are similar for many of the statements. These results do not account for other factors which may influence perceptions about the SFA system such as hours of work, station productivity and perceptions about training. Thus the data are further analyzed using regression analysis on the statements with training, productivity and hours of work as well as experience as independent variables.

Although the survey was developed to examine both productivity and system functionality perceptions, the strong negative perceptions of the system could result in perceptions of productivity and system functionality being highly correlated. As a result separate regressions for each of these statements will lead to redundancies. ${ }^{2}$ To reduce the number of dependent variables, factor analysis was applied to the eleven statements discussed above (see Tables 1-3). Two factors loaded with an Eigenvalue greater than one, reducing the 11 statements into two factors. The first factor includes all of the statements except the statement: "The purpose of the system is to allow upper management to more closely manage sales personnel," which loaded as the second factor.

The overall satisfaction and system functionality are highly related to the productivity variables because most of the users were dissatisfied with the productivity of the system. If the users had found the system resulted in higher productivity, the correlation between the system functionality variables and productivity variables might have been lower and the system functionality variables would likely have loaded separately. As such, a single productivity measure is used in the analysis which is the average of the ten productivity/system functionality variables. ${ }^{3}$ The second factor loaded for the micromanagement statement "The purpose of the system is to allow upper management to more closely manage sales personnel."

To determine the effect of experience on the perceptions of the system, two regressions are estimated using the productivity measure and the micromanagement statement responses as the dependent variables. The independent variables are experience, hours of work, months sales goals were met and whether the recruiter found training to be helpful on an aggregated variable that measures productivity.

The means for these variables are shown in Table 4. The average of the productivity variable was 3.57, which is a little below a neutral response average of 4 . The micromanagement variable has a mean of 5.5, which implies that most of the respondents think that the system is used as a tool by upper level management to manage personnel. One-third of the respondents have more than 2 years of experience. Most recruiters reported that they worked at least than 50 hours per week. Stations met their mission on average 3.4 of the last twelve months. The response to the training statement was above the neutral range. Many felt that their training was adequate.

\footnotetext{
${ }^{2}$ In fact, this is the case. A regression was estimated for each statement. Results were quite similar to the overall results reported below.

${ }^{3}$ Another measure would weight this variable based upon the factor loadings. An analysis using this weighting scheme gave similar results.
} 
Table 3: Perceptions of System Functionality by Experience

\begin{tabular}{|c|c|c|c|c|c|c|c|c|c|}
\hline \multicolumn{10}{|c|}{$\begin{array}{c}\text { Hypothesis 4: More experienced salespeople are less likely to be satisfied with SFA system functionality than less } \\
\text { experienced salespeople }\end{array}$} \\
\hline Statement & $\begin{array}{c}\text { Experience } \\
\text { Level }\end{array}$ & $\begin{array}{c}\text { Strongly } \\
\text { Disagree } \\
(\%) \\
\end{array}$ & $\begin{array}{c}\text { Disagree } \\
(\%)\end{array}$ & $\begin{array}{c}\text { Slightly } \\
\text { Disagree } \\
(\%) \\
\end{array}$ & $\begin{array}{c}\text { Neutral } \\
(\%)\end{array}$ & $\begin{array}{c}\text { Slightly } \\
\text { Agree } \\
(\%)\end{array}$ & $\begin{array}{c}\text { Agree } \\
(\%)\end{array}$ & $\begin{array}{c}\text { Strongly } \\
\text { Agree } \\
(\%)\end{array}$ & $x^{2}$ \\
\hline \multirow{3}{*}{$\begin{array}{l}\text { Information } \\
\text { provided by } \\
\text { the system is } \\
\text { accurate }\end{array}$} & $\mathrm{LE}^{*}$ & $\begin{array}{c}66 \\
(5.9 \%)\end{array}$ & $\begin{array}{c}136 \\
(8.2 \%)\end{array}$ & $\begin{array}{c}181 \\
(10.9 \%)\end{array}$ & $\begin{array}{c}243 \\
(14.7 \%)\end{array}$ & $\begin{array}{c}233 \\
(14.1 \%)\end{array}$ & $\begin{array}{c}240 \\
(14.5 \%)\end{array}$ & $\begin{array}{c}12 \\
(0.7 \%)\end{array}$ & \multirow[t]{2}{*}{$11.6^{\mathrm{c}}$} \\
\hline & $\mathrm{ME}$ & $\begin{array}{c}35 \\
(6.4 \%)\end{array}$ & $\begin{array}{c}90 \\
(16.5 \%)\end{array}$ & $\begin{array}{c}92 \\
(16.9 \%)\end{array}$ & $\begin{array}{c}91 \\
(16.7 \%)\end{array}$ & $\begin{array}{c}109 \\
(20.0 \%)\end{array}$ & $\begin{array}{c}126 \\
(23.1 \%)\end{array}$ & $\begin{array}{c}3 \\
(0.6 \%)\end{array}$ & \\
\hline & Overall & $6.1 \%$ & $13.6 \%$ & $16.5 \%$ & $20.2 \%$ & $20.6 \%$ & $20.1 \%$ & $0.9 \%$ & \\
\hline \multirow{3}{*}{$\begin{array}{l}\text { The amount } \\
\text { of time } \\
\text { required is } \\
\text { reasonable }\end{array}$} & LE & $\begin{array}{c}129 \\
(11.6 \%)\end{array}$ & $\begin{array}{c}196 \\
(17.6 \%)\end{array}$ & $\begin{array}{c}189 \\
(17.0 \%)\end{array}$ & $\begin{array}{c}235 \\
(21.2 \%)\end{array}$ & $\begin{array}{c}180 \\
(16.2 \%)\end{array}$ & $\begin{array}{c}173 \\
(15.6 \%)\end{array}$ & $\begin{array}{c}9 \\
(0.8 \%)\end{array}$ & \multirow{2}{*}{$21.7^{\mathrm{a}}$} \\
\hline & $\mathrm{ME}$ & $\begin{array}{c}87 \\
(15.9 \%)\end{array}$ & $\begin{array}{c}133 \\
(24.2 \%)\end{array}$ & $\begin{array}{c}87 \\
(15.9 \%)\end{array}$ & $\begin{array}{c}87 \\
(15.9 \%)\end{array}$ & $\begin{array}{c}76 \\
(13.9 \%)\end{array}$ & $\begin{array}{c}75 \\
(13.7 \%)\end{array}$ & $\begin{array}{c}2 \\
(0.4 \%)\end{array}$ & \\
\hline & Overall & $13.0 \%$ & $19.8 \%$ & $16.7 \%$ & $19.4 \%$ & $15.5 \%$ & $15.0 \%$ & $0.7 \%$ & \\
\hline \multirow{3}{*}{$\begin{array}{l}\text { The system } \\
\text { provides } \\
\text { flexibility }\end{array}$} & LE & $\begin{array}{c}80 \\
(7.2 \%)\end{array}$ & $\begin{array}{c}178 \\
(16.0 \%)\end{array}$ & $\begin{array}{c}169 \\
(15.2 \%)\end{array}$ & $\begin{array}{c}346 \\
(31.1 \%)\end{array}$ & $\begin{array}{c}204 \\
(18.4 \%)\end{array}$ & $\begin{array}{c}127 \\
(11.4 \%)\end{array}$ & $\begin{array}{c}7 \\
(0.6 \%)\end{array}$ & \multirow{2}{*}{$17.2^{\mathrm{a}}$} \\
\hline & $\mathrm{ME}$ & $\begin{array}{c}65 \\
(11.9 \%)\end{array}$ & $\begin{array}{c}100 \\
(18.3 \%)\end{array}$ & $\begin{array}{c}92 \\
(16.9 \%)\end{array}$ & $\begin{array}{c}142 \\
(26.0 \%)\end{array}$ & $\begin{array}{c}82 \\
(15.0 \%)\end{array}$ & $\begin{array}{c}60 \\
(11.0 \%)\end{array}$ & $\begin{array}{c}5 \\
(0.9 \%)\end{array}$ & \\
\hline & Overall & $8.8 \%$ & $16.8 \%$ & $15.8 \%$ & $29.5 \%$ & $17.3 \%$ & $11.3 \%$ & $0.7 \%$ & \\
\hline \multirow{3}{*}{$\begin{array}{l}\text { The system } \\
\text { helps me } \\
\text { more } \\
\text { effectively } \\
\text { perform my } \\
\text { duties }\end{array}$} & LE & $\begin{array}{c}75 \\
(6.8 \%)\end{array}$ & $\begin{array}{c}149 \\
(13.4 \%)\end{array}$ & $\begin{array}{c}155 \\
(14.0 \%)\end{array}$ & $\begin{array}{c}311 \\
(28.0 \%)\end{array}$ & $\begin{array}{c}244 \\
(22.0 \%)\end{array}$ & $\begin{array}{c}161 \\
(14.5 \%)\end{array}$ & $\begin{array}{c}16 \\
(1.4 \%)\end{array}$ & \multirow{2}{*}{$55.1^{\mathrm{a}}$} \\
\hline & $\mathrm{ME}$ & $\begin{array}{c}47 \\
(13.6 \%)\end{array}$ & $\begin{array}{c}121 \\
(22.2 \%)\end{array}$ & $\begin{array}{c}83 \\
(15.2 \%)\end{array}$ & $\begin{array}{c}120 \\
(22.0 \%)\end{array}$ & $\begin{array}{c}94 \\
(16.7 \%)\end{array}$ & $\begin{array}{c}54 \\
(10.0 \%)\end{array}$ & $\begin{array}{c}3 \\
(0.6 \%)\end{array}$ & \\
\hline & Overall & $9.0 \%$ & $16.3 \%$ & $14.4 \%$ & $26.0 \%$ & $20.2 \%$ & $13.0 \%$ & $1.2 \%$ & \\
\hline \multirow{3}{*}{$\begin{array}{l}\text { Overall I am } \\
\text { satisfied } \\
\text { with the } \\
\text { system }\end{array}$} & LE & $\begin{array}{c}98 \\
(8.8 \%)\end{array}$ & $\begin{array}{c}163 \\
(14.7 \%)\end{array}$ & $\begin{array}{c}167 \\
(15.0 \%)\end{array}$ & $\begin{array}{c}334 \\
(30.1 \%)\end{array}$ & $\begin{array}{c}196 \\
(17.6 \%)\end{array}$ & $\begin{array}{c}143 \\
(12.9 \%)\end{array}$ & $\begin{array}{c}10 \\
(0.9 \%)\end{array}$ & \multirow{2}{*}{$22.9^{\mathrm{a}}$} \\
\hline & $\mathrm{ME}$ & $\begin{array}{c}81 \\
(14.8 \%)\end{array}$ & $\begin{array}{c}104 \\
(19.1 \%)\end{array}$ & $\begin{array}{c}87 \\
(15.9 \%)\end{array}$ & $\begin{array}{c}124 \\
(22.7 \%)\end{array}$ & $\begin{array}{c}87 \\
(15.9 \%)\end{array}$ & $\begin{array}{c}61 \\
(11.2 \%)\end{array}$ & $\begin{array}{c}2 \\
(0.4 \%)\end{array}$ & \\
\hline & Overall & $10.8 \%$ & $16.1 \%$ & $15.3 \%$ & $27.6 \%$ & $17.1 \%$ & $12.3 \%$ & $0.7 \%$ & \\
\hline
\end{tabular}

*EE is less experienced, ME is more experienced

${ }^{\text {a Significant at } \mathrm{p}<0.01}$

${ }^{\text {b Significant at } p<0.05}$

${ }^{\mathrm{c}}$ Significant at $\mathrm{p}<0.10$

The regression results are in Table 5. The results in column 1 show that the more experienced recruiters were more likely to perceive that the system reduced their productivity. Their perception about the productivity of the system is 0.39 points lower than that of less experienced recruiters. This corresponds to the individual Chisquare results in the previous tables.

Recruiters who indicated that they had longer work weeks were more likely to perceive that the system reduced their productivity relative to those who worked less than 50 hours per week. When we tested whether the individual hours of work coefficients differed from each other, however, there is no statistical difference between workers working 60 to 70 and greater than 70 hours per week, but both these coefficients are significantly different from the one for hours between 50 and 60 per week. Thus, recruiters who worked more hours per week were much more likely to feel that their productivity was reduced by the system. 
Table 4: Means of Regression Variables

\begin{tabular}{|l|c|c|}
\hline Variable & Mean & Standard Deviation \\
\hline Average of the productivity variables & 3.57 & 1.17 \\
\hline Micromanage & 5.50 & 0.47 \\
\hline Experience > 2 years & 0.33 & 0.19 \\
\hline Recruiter works <50 hours/wk (omitted category) & 0.05 & 0.45 \\
\hline Recruiter works 50-60 hours/wk & 0.29 & 0.50 \\
\hline Recruiter works 60-70 hours/wk & 0.43 & 0.42 \\
\hline Recruiter works >70 hours/wk & 0.23 & 2.89 \\
\hline Number of months the station met its mission & 3.40 & 1.69 \\
\hline Training was helpful & 4.41 & \\
\hline Sample Size & 1,657 & \\
\hline
\end{tabular}

Table 5: Regression Results for Productivity and Micromanagement Variables

\begin{tabular}{|l|c|c|}
\hline Variable & Productivity & Micromanagement \\
\hline Experience $>$ 2 years & $-0.39(0.05) \mathbf{a}$ & $0.17(0.07) \mathbf{b}$ \\
\hline Recruiter works 50-60 hours/wk & $-0.16(0.13)$ & $0.35(0.17) \mathbf{b}$ \\
\hline Recruiter works 60-70 hours/wk & $-0.33(0.13) \mathbf{a}$ & $0.38(0.17) \mathbf{b}$ \\
\hline Recruiter works >70 hours/wk & $-0.39(0.13) \mathbf{a}$ & $0.26(0.18)$ \\
\hline Number of months the station met its mission & $0.00(0.01)$ & $-0.02(0.01)$ \\
\hline Training was helpful & $0.30(0.02) \mathbf{a}$ & $0.10(0.02) \mathbf{a}$ \\
\hline Intercept & $2.99(0.16) \mathbf{a}$ & $4.75(0.19) \mathbf{a}$ \\
\hline F (p-value) & $79.55(0.0001)$ & $5.94(0.0001)$ \\
\hline R-Square & 0.22 & 0.02 \\
\hline
\end{tabular}

The productivity of the recruiting station as measured by the number of months that the station met mission did not affect the response on productivity. This can be interpreted that these recruiters were not using the system as an excuse for poor outcomes in meeting their sales goals.

Recruiters who found training to be helpful were more likely to perceive that the system improved productivity. This strongly suggests that better training will lead to better acceptance of the system. This likely follows from a better understanding of the system's capabilities.

The micromanagement statement was "The purpose of the system is to allow upper management to more closely manage sales personnel." The regression results in column two show that recruiters with more experience were more likely to think that the system was being used as a micromanagement tool. This is consistent with the hypothesis. The more experienced recruiters are more likely to have their own routines and less likely to want any change in these routines.

Generally, recruiters who worked greater than 50 hours per week were more likely to think that the system was being used as a micromanagement tool. Whether a recruiting station was making mission has no effect on the perception of micromanagement. Individuals who found training to be helpful were more likely to perceive the system as a micromanagement tool. This likely reflects their better understanding of the system's capabilities and how it could be used to micromanage the recruiting stations.

\section{Conclusions}

It has been shown that sales people's perceptions of SFA technologies may influence their acceptance of the technologies. The results in this study demonstrate that perceptions of SFA technologies may vary by sales experience. The results indicate that more experienced salespeople tend to have more negative perceptions about the SFA system than their less experienced counterparts. Relative to less experienced sale people, the more experienced 
sales people are less likely to perceive productivity gain through the use of an SFA system; more likely to perceive an SFA system as a micromanagement tool; and less likely to be satisfied with the functionality of an SFA system.

The results in the study have clear implications for sales organizations that are considering adopting SFA technologies. As salespeople gain more experience in sales, they will develop skills and tools best suited to their individual sales style. Therefore, they become more entrenched with these tools and the sales routine that produces the best results. Because rewards usually accompany successful efforts, the more experienced salespeople are thus more likely to cling to the processes and tools that have been successful for them in the past. For these workers, having the SFA system imposed on them may be perceived as a major impediment to their proven and successful routines, and thus may prevent them for achieving the rewards that they received in the past. This may result in less acceptance of the system, and more negative perceptions of the technology.

Conversely, less experienced salespeople may be less likely to have developed an optimal routine, so they will be more inclined to find the SFA tool useful. They may be more inclined to try out different tools and techniques, as they seek out their "best" sales process. Acceptance of SFA systems, to less experienced salespeople, may represent an opportunity to achieve the rewards of successful sales efforts. Since their habits are less established, and their attainment of success less certain, acceptance of the technology may be easier to achieve since they have "less to lose."

To improve acceptance and utilization of SFA systems, organizations must not only address the sales force's perceptions of the system, they must also anticipate that more experienced salespeople will a priori have a different set of perceptions than their less experienced counterparts. Since sales experience seems to have a negative impact on SFA perceptions, more experienced salespeople should be introduced to SFA technology in a different manner than the less experienced salespeople. For example, for the more experienced salespeople, the system should take into account their routines and be tailored to complement those routines. Flexibility in how the salespeople apply the SFA utilization should be at a premium. In short, the SFA should fit the salesperson; the organization should not try to change the salesperson to fit the system.

The differences in perceptions about the SFA system may likely be attributed to a lack of input from more experienced users in the design of the system. Design features often can be driven more by management perceptions of the ideal sales process rather than the actual perceptions of the experienced sales force. In the design stage, it is important to involve more experienced users in the analysis phase of system development, where the requirements of the functionality of the system are defined. This would allow their input to drive system features that actually support the sales process. Once a system has been implemented, it is also important to determine if perceptions of the functionality differ by experience and, if so, modify the system based upon recommendations of the users in subsequent releases.

One of the main objectives of the SFA system is to also improve the efficiency of the sales management process. However, this is often perceived, and is shown in this study, to be a means for management to micromanage the sales force. More experienced people are more likely to have this perception because they typically have a greater amount of autonomy to lose. This perception of supervision can be either active or passive depending on the design functionality of the system. Active supervision is a direct affront to the more experienced salesperson since they are unlikely to have experienced this level of scrutiny previously. It is important to design the system so that this perception is minimized as much as possible. While management of the sales force is important, it should not come at the expense of alienating the more experienced salespeople, which may have an accompanying negative impact on sales and result in rejection of the system. During implementation of the system, the firm should emphasize the benefits to the salespeople to maximize "buy in" while acknowledging and minimizing the impact of micromanagement.

There are several limitations to this study. First, the research has only considered one organization, and despite the fact that the sample is fairly large, generalizability beyond this single organization must be done carefully. Future research should focus on different industries and multiple organizations. More research with additional organizations should be performed in the future to determine if these results can be replicated. Second, 
this study is not longitudinal, so the attenuation of resistance to the SFA system should also be addressed in future studies. It is uncertain how the acceptance of the SFA technology will change over time, as the more experienced salespeople leave the organization due to attrition, and are replaced by less experienced salespeople. Since this study is the first to examine the association of sales experience with SFA acceptance, it provides a basis for future studies examining the effect of sales experience on perceptions of SFA systems.

\section{References}

1. $\quad$ Ajzen, I. The theory of planned behavior. Organizational Behavior and Human Decision Processes 1991; (50):179-211.

2. $\quad$ Blodgett, M. "Vendor tries to simplify sales force automation". Computerworld 1995; 30(1):62-62.

3. Engle, RL., Barnes, ML. "Sales force automation usage, effectiveness, and cost-benefit in Germany, England and the United States". Journal of Business \& Industrial Marketing 2000; 15(4):216-241.

4. Erffmeyer, RC., Johnson, DA. "An Exploratory study of sales force automation practices: expectations and realities". Journal of Personal Selling \& Sales Management 2001; XXI (2):167:175.

5. $\quad$ Falvey, J. On guard. Sales \& Marketing Management 1994; January: 41-41.

6. $\quad$ Fisher, Lawrence M. "Here comes front-office automation". Strategy and Business 1998; 13 (4):53-65.

7. Gondert, S. "Automation: the 10 biggest mistakes of SFA (and how to avoid them)". Sales and Marketing Management 1993; 145(2):52-57.

8. Hackman, R., Oldham, G. Work Redesign. Reading, MA: Addison-Wesley Publishing, 1980.

9. Johnston, WJ. Editorial. The Journal of Business \& Industrial Marketing 1995; 10(2):4-6.

10. Keillor, BD., Bashaw, RE., Pettijohn, CE. "Salesforce automation issue prior to implementation: the relationship between attitudes toward technology, experience, and productivity". The Journal of Business \& Industrial Marketing 1997; 12(3):209-219.

11. Li, EY., McLeod R., Rogers, JC. "Marketing information systems in fortune 500 companies: a longitudinal analysis of 1980, 1990, 2000". Information \& Management 2001; 38(5):307-322.

12. Mahmood MA, Burn JM, Gemoets LA, Jacquez C. "Variables affecting information technology end-user satisfaction: a meta-analysis of the empirical literature". Int. J. Human-Computer Studies 1999; 52:751-771.

13. McLeod, R., Rogers, JC. "Marketing information systems: uses in the fortune 500". California Management Review 1982; 25:106-118.

14. Morgan, A. J., Inks, S. A. "Technology and the sales force: increasing acceptance of sales force automation". Industrial Marketing Management 2001; 30(5):463-472.

15. Morris, MG, Venkatesh, V. "Age differences in technology adoption decisions: implications for a changing work force". Personnel Psychology 2000; 53:375-403.

16. Parthasarathy, M., Sohi, RS. "Sales force automation and the adoption of technological innovations by salespeople: theory and implications". Journal of Business \& Industrial Marketing 1997; 12(3):196-208.

17. Pullig, C., Maxham JG. III, Hair, JF. "Sales force automation systems: an exploratory examination of organizational factors associated with effective implementation and sales force productivity". Journal of Business Research 2002; 55:401-415.

18. Regan, DT, Fazio, RH., "On the consistency between attitudes and behaviors: Look to the method of attitude formation". Journal of Experimental and Social Psychology 1977; 13, 38-45.

19. Rivers, LM, Dart, J. "The acquisition and use of sales force automation by mid-sized manufacturers". Journal of Personal Selling \& Sales Management 1999; XIX(2, Spring):59-73.

20. Schafer, S. “Supercharged sell”. Inc., Technology Supplement 1997; 19(June 17):42-52.

21. Speier, C., Venkatesh, V. "The hidden minefields in the adoption of sales force automation technologies". Journal of Marketing 2002; 66(July):98-111.

22. Stein, T. "Software for the hard sell--by adding functionality, sales force automation systems are overcoming a bad reputation". InformationWeek 1998; 671(March):18-19.

23. Webster J, Martocchio JJ. "The different effects of software training previews on training outcomes". Journal of Management 1995; 21(4):757-787. 